\title{
Puuvartiset viherrakentamiskasvien harvinaisuudet
}

\author{
Marjatta Uosukainen \\ MTT, Kasvintuotannon tutkimus, Antinniementie 1, 41330 Vihtavuori, marjatta.uosukainen@mtt.fi
}

\section{Tiivistelmä}

Puutarhakasvien kokeilut alkoivat Suomessa jo keskiajalla ja puutarhatalous elinkeinona alkoi kehittyä maassamme 1700-luvulla. Suomeen on viimeisten 400 vuoden aikana kulkeutunut vierasperäisiä kasvilajeja puutarhoissa viljeltäviksi ja puistoihin ja puutarhoihin istutettaviksi. Aluksi kasvivalikoima oli varsin suppea ja valikoima palveli kaupunkirakentamisessa ensisijaisesti paloturvallisuutta.

Puistojen rakentaminen yleistyi kaupungeissa 1800-luvulla ja samalla alkoi myös määrätietoinen ulkomaisten kasvilajien kokeilu kasvitieteellisillä puistoissa ja Metsähallinnon kokeilumetsiköissä. Helsingin kaupunki oli etunenässä istuttamassa vieraita kasvilajeja lisäämään kaupunkiasukkaiden tuohon aikaan varsin ankean elinympäristön viihtyisyyttä. Suomeen tulivat perinteikkäät koristekasvit, kuten syreenit, omenapuut, vaahterat, ruusut jne. Vuosisadan vaihtuessa 1900-luvun alussa kasvien saatavuus parani suurten kansainvälisten kasviretkikuntien työn tuloksena. Kasvivalikoimaamme tulivat amerikkalaisten ja eurooppalaisten lajien lisäksi japanilaiset, korealaiset ja kiinalaiset kasvilajit.

Helsingissä vuonna 2005 valmistuneessa kartoituksessa rekisteröitiin yli 200 lehtipuulajia tai lajiketta. Suomeen kotiutetuista ja täällä hyödynnetyistä kasviharvinaisuuksista merkittävimmät ovat alppiruusut, erityisesti mustilanalppiruusu (Rhododendron brachycarpum subsp. tigerstedtii Nitz.), höyhenpensas (Fothergilla major (Sims) Loddiges), hortensiat (Hydrangea sp.), koristekirsikat (Prunus sp.), magnoliat (Magnolia sp.)sekä kotakuusamat (Weigela sp.) ja kellokuusama (Kolkwitzia amabilis Graebn.).

Puutarhojen ja puistojen kasveja valittaessa luonnonkasvien antamat mahdollisuudet ovat meillä jääneet vähälle huomiolle. Havupuista katajan lisäksi meillä on kauniita muotoja erityisesti kuusesta. Kotimaisten puulajien erikoismuotoja on kerätty Metsäntutkimuslaitoksen rekisteriin ja istutuksiin näytetarhoihin. Joitakin erikoistyyppejä on aika-ajoin lisätty taimimyyntiä varten. Suomessa on vain pari kotimaisten kasvilajien taimien tuotantoon erikoistunutta taimitarhaa, joten kotimaisten havupuiden erikoismuotojen taimia on niukasti saatavilla.

Harvinaisuudet osoittavat, että meillä arkojenkin lajien sisällä on vaihtelua, joka sellaisenaan monipuolistaa meillä viljeltävien kasvien valikoimaa. Ne myös osoittavat, että geneettistä vaihtelua voidaan hyödyntää kasvinjalostuksessa ja siten parantaa lajikkeistomme viljelyvarmuutta. Suomessa vuosikymmeniä menestyneet kasviyksilöt ovat myös maailmanlaajuisesti merkityksellisiä, sillä ne ovat meillä altistuneet ankaralle luonnonvalinnalle, jossa kriittisiä tekijöitä ovat keskitalven kylmänkestävyys, kasvukauden aikainen kuivuuden sieto, nopea kasvurytmi ja sen seurauksena sadon aikaisuus.

\section{Asiasanat}

Havupuiden erikoismuodot, höyhenpensas, japaninmagnolia, keltakotakuusama, kellokuusama, kääpiömanteli.

\section{Johdanto}

Puutarhakasvien kokeilut alkoivat Suomessa keskiajalla linnanpuistoissa ja 1500-luvulta eteenpäin kartanoiden puutarhoissa. Aluksi kokeiltiin hedelmäpuita, koristeistutukset ilmestyivät 1600-luvulle tultaessa (Häyrynen 2008) ja ulkomaisilla puulajeilla perustetut koristeistutukset alkoivat yleistyä hyötypuutarhojen oheen1700-luvulla. Ruotsalaiset taimistot olivat koko 1800-luvun ajan merkittäviä puuvartisten kasvien taimitoimittajia sillä Suomen taimitarhaviljely oli 1800-luvun puolivälissä vaatimatonta ja taimivalikoimat melko suppeat. Ulkomailta tuotiin lehmuksen, vaahteran ja hevoskastanjan taimia ja yleensä kaikilla taimimyyjillä oli 1800-luvun puolivälissä saatavissa pihasyreenin (Syringa vulgaris L.), kiinansyreenin (S. x chinensis Willd.) ja unkarinsyreenin (S. josikaea Jacq. f. ex Rchb.) taimia. Puistoissa käytettiin 1800-luvulla myös luonnonvaraisia kasveja, kuten pähkinäpensas (Corylus avellana L.), lehtokuusama (Lonicera xylosteum L.), punakoiso (Solanum dulcamara L.) ja koiranheisi (Viburnum opulus L.). Nykyisistä suosikkikasveista pallohortensiat (Hydrangea arborescens L) saapuivat Suomeen ennen 1850-lukua, syyshortensia (Hydrangea paniculata Siebold) tuotiin Eurooppaan 1800-luvun loppupuolella. Alppiruusut tulivat hinnastoihin ensin ruukkukasveina 1840luvulla ja vuodesta 1884 myös avomaanistutuksiin. (Nummi 2008). 
Taimitarhaviljelyn nousukausi alkoi 1870-luvulla: 1850-luvulla Suomessa oli 4-5 kaupallista taimitarhaa, 1880-luvulla 15 ja 1900-luvun alussa oli noin 40 taimistoa. Yhteensä vuosina 1900-1918 perustettiin noin 25 taimitarhaa. Taimien tarve kasvoi tällä kaudella julkisten istutusten laajetessa ja yksityisten puutarhojen määrän kasvaessa. (Nummi 2008). Vierasperäiset kotiutetut kasvilajit monipuolistavat merkittävästi puistojemme ja puutarhojemme kasvivalikoimaa, koska kotoperäisten lajien valikoima on niukka. Kasvilajien kotiuttaminen Suomeen on varsin monivaiheinen työ. Erehdysten kautta on opittu, että todennäköisyys onnistuneelle tulokselle on suurempi, mikäli kasvien alkuperien valinnassa ollaan tarkkoja ja tänne yritetään kotiuttaa vain kasveja, joiden alkuperä on Suomea ilmastollisesti vastaavilta alueilta. (Hämet-Ahti 1970, Hämet-Ahti ym. 1992). Ilmaston tuoma valintapaine on kova ja vähitellen joukosta karsiutuvat pois heikosti sopeutuneet aineistot. Aina silloin tällöin joukosta valikoituu erityisen hyviä käyttökelpoisia siemenlähteitä, tai muutamia kasviyksilöitä, joskus vain yksi muita selvästi ylivoimaisempi yksilö. Jos näin käy, on kysymyksessä jo yleensä kestävyydeltään maailmanlaajuisestikin ainutlaatuinen geenivara, varsinainen lottovoitto.

\section{Uusien lajien kotiuttaminen}

Kasveja on kotiutettu Suomeen määrätietoisesti arboretumien, kaupunkipuistojen, kasvitieteellisten puutarhojen ja sekä muiden puistoistutusten kautta 1800-luvulta lähtien (Jäppinen 1996, Nummi 2008, Koponen 2008). Kaupunkien puistoihin ja julkisia rakennuksia ympäröiville viheralueille ja muille vastaaville paikoille on syntynyt merkittäviä ja monilajisia kasvikokoelmia, joiden lajivalikoima voi olla yllättävän runsas. Helsingissä vuonna 2003 tehdyn selvityksen mukaan kaupunkiin vuosina 19301950 perustetuissa puistoissa esiintyy yli 200 istutettua lehtipuulajia tai lajiketta, vaikka selvitykseen otettiin vain harvinaisimmat istutetut puut. Todellisuudessa laji- ja lajikevalikoima on huomattavasti suurempi. (Mustiala 2005). Hyvänä esimerkkinä uraa uurtavasta työstä ovat helsinkiläiset koristeomenapuut (Temmes 2007) ja syreenit (Hauta-aho 2006).

Arboretumtoiminta alkoi Suomessa Turun Akatemian aikana 1700-luvun puolivälissä ja jatkui 1800-luvulla kasvitieteellisillä puistoissa ja Metsähallinnon kokeilumetsiköissä. Määrätietoinen arboretumien perustaminen alkoi 1900-luvun alussa, jolloin yksityiset henkilöt, yliopistot, kaupungit, teollisuuslaitokset ja oppilaitokset jne. alkoivat perustaa puuvartisten kasvien kokoelmia. (Nummi 2008). Suomen tunnetuin puulajipuisto on Arboretum Mustila, jonka perusti valtioneuvos Axel Fredrik Tigerstedt vuonna 1902. Mustilan pinta-ala on 120 hehtaaria ja alueella on yli 1000 lajia puita ja pensaita, joista alppiruusu- ja havupuukokoelmat ovat huomattavimmat (Koponen 2008).

Viherrakentamisessa käyttökelpoisia uusia kasveja löytyy kasvikokoelmista edelleenkin, osa niistä on Suomessa varsin harvinaisia. Kasvinjalostus on toistaiseksi hyödyntänyt näistä harvinaisuuksista vain alppiruusut, joilla käynnistettiin jalostusohjelma vuonna 1973 (Uosukainen 1992, 1993, 2006a, 2008, Uosukainen \& Tigerstedt 1988). Alppiruusujen jalostusohjelma perustui Mustilaan Koreasta 1920-luvulla kulkeutuneeseen poikkeuksellisen kestävään japaninalppiruusun alalajiin, mustilanalppiruusuun (Rhododendron brachycarpum subsp. tigerstedtii Nitz.) (Nitzelius 1970, Hagman \& Autio 1999). Suomen ankarassa ilmastossa lajin erinomainen kylmänkestävyys tuli ilmi ja alan kirjallisuudessa lajia pidetään maailman kestävimpänä alppiruusuna (Cox 1979). On olemassa useita vastaavia esimerkkejä kasviharvinaisuuksista, joita olisi mahdollista hyödyntää meillä yleisemminkin viherrakentamisessa ja kasvinjalostuksessa. Kasvien nimissä on ensisijaisesti käytetty Viljelykasvien nimistöä (Räty \& Alanko 2004).

\section{Löytöjä valikoimasta \\ Höyhenpensas}

Taikapähkinöihin (Hamamelidaceae) kuuluva höyhenpensas (Fothergilla major (Sims) Loddiges) 'Velho' on Suomessa harvinainen erikoisuus, jonka emopensas löytyi Mustilan arboretumista 1970luvulla. Se menestyy hyvin ainakin vyöhykkeillä I-III. Kanta on Eviran hyväksymä ydinkasvi ja on saanut myös FinE ${ }^{\circledR}$-laatumerkin (Uosukainen 2006b). Höyhenpensas on vaikea lisättävä, mutta MTT:n Laukaan toimipaikan laboratoriossa sitä on mikrolisätty 1980-luvun alusta lähtien. Höyhenpensas ei ole puistojen massakasvi vaan intiimien puutarhojen helmi. (Alanko \& Lagerström 2009). Tuoksuvan, tähkämäisen kukinnon erikoinen, lamppuharjamainen ulkonäkö (kuva 1.) johtuu siitä, että kukissa ei ole lainkaan terälehtiä, vaan ainoastaan emit ja pitkät valkeat heteet (Hämet-Ahti ym. 1992). Kiiltävän tummanvihreät, pyöreähköt, lehdet saavat keltaisen tai joskus loistavan oranssin punaisen syysvärin (kuva 2.). 'Velho' on täysikasvuisena noin 1,2 m korkea pensas, jolla ei juuri esiinny tuholaisia. 


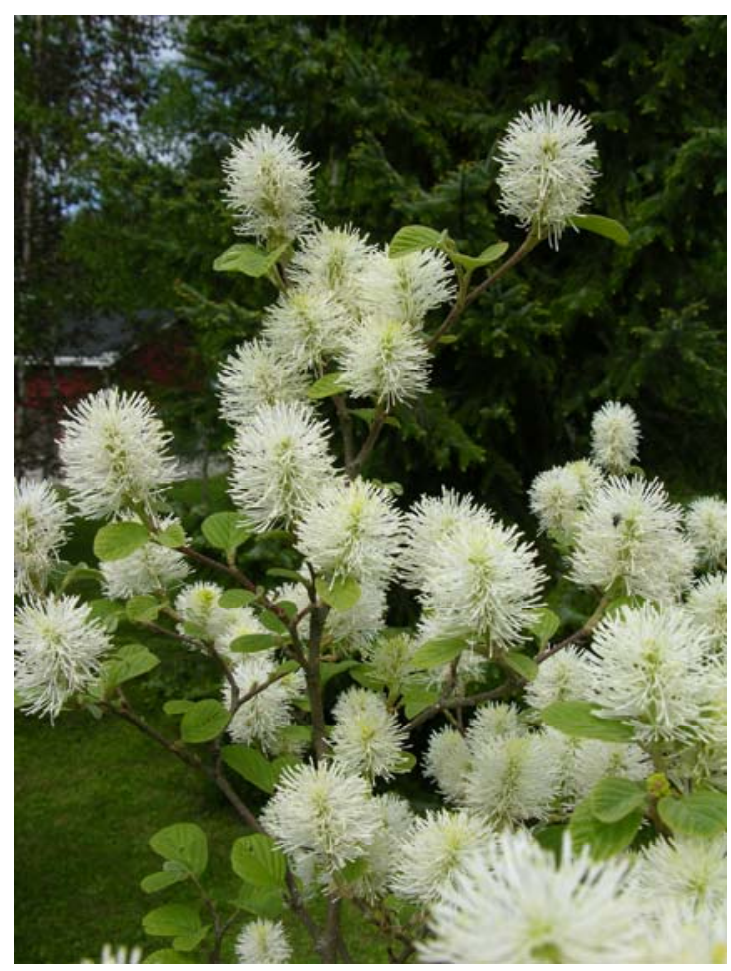

Kuva 1. Höyhenpensaan (Fothergilla major) lajike Velho on matalakasvuinen, keväällä ja alkukesällä kukkiva pensas. Marjatta Uosukainen

\section{Hortensiat}

Kiinanhortensiat (Hydrangea heteromalla D.Don) ovat Mustilassa osoittaneet erinomaista sopeutumiskykyä Suomen ilmastoon pystyen tekemään siementaimia luontaisesti. Yksi puistosta löydetty siementaimi osoittautui lajissaan kukinnaltaan varsin poikkeukselliseksi ja siitä on tehty oma lajike nimeltään Bougie (Uosukainen 2006c). Lajikkeen kukinnossa valekukat ovat kerrannaiset. Kukinnan edetessä valekukkien lehtien nivelvälit kasvavat ja kukinnosta muodostuu riippuva. Mustilasta on peräisin myös ainutlaatuinen japaninhortensian (H. paniculata Siebild) perusmuoto, FinE ${ }^{\circledR}$-nimetty lajike Mustila, joka tunnetaan suomalaisella nimellä mustilanhortensia. Koska Suomessa on myös muita meille hyvin sopeutuneita hortensialajeja ja kantoja, olisi meillä tässä myös hyvä pohja kasvinjalostukselle.

\section{Kellokuusama}

Vanamokasveihin (Linnaeae) kuuluva kellokuusama (Kolkwitzia amabilis Graebn.) on kauneimpia Suomessa menestyviä pensaita. Laji kasvaa luontaisena Keski-Kiinassa, josta se kulkeutui Yhdysvaltoihin ja Eurooppaan vasta vuonna 1901 (Alanko \& Lagerström 2009). Kukinnan alkaessa heinäkuussa, kellomaiset vaaleanpuna-valkoiset, nielustaan keltatäpläiset kukat peittävät kaarevaoksaisen siron pensaan täysin. Kukat ovat hyvän tuoksuiset, noin 2 cm leveät. (Hämet-Ahti ym. 1992). Lajin menestymisalueena pidetään vain kasvuvyöhykkeitä Ia ja Ib (Räty 2009). Talvehtimisongelmien vuoksi pensas kasvaa meillä harvoin yli metrin korkuiseksi muualla kuin aivan etelä-rannikolla (Alanko \& Lagerström 2009). Lajista on kulkeutunut Suomeen lukuisia eri alkuperiä ja eräs kestävimpiä yksilöitä on menestynyt vuosikymmeniä Mustilassa vyöhykkeellä III. Tämä Kellokas-nimen saanut kanta on valittu säilytettäväksi Suomessa geenivarana. Klooni on menestynyt Mustilan lisäksi myös Jyväskylän pohjoispuolella Laukaassa aivan menestymisvyöhykkeen IV rajalla. Laukaassa on todettu, että typpilannoituksella kellokuusama rehevöityy herkästi ja rehevä pensas talvehtii heikosti.

\section{Magnoliat}

Magnolioita tunnetaan 80 lajia Itä-Aasiasta, Pohjois- ja Keski-Amerikasta ja Himalajalta. Ne ovat maailmalla puistomaisissa istutuksissa suosittuja suurikukkaisia puita ja pensaita. Suomessa on vyöhykkeillä I-III osoittautunut kestäviksi kolme magnolialajia, joita voitaisiin meillä viljellä erikoiskasveina. (Alanko \& Tegel 1989, Uosukainen 2006b). Japaninmagnolia (Magnolia kobus DC. var. borealis) on komein meillä menestyvä magnolia. Puu kukkii lehdettömänä varhain toukokuussa valkoisin, teekupin kokoisin kukin (kuvat 3.-4.). Lajin käyttö on Suomessa toistaiseksi vähäistä, koska saatavilla ei ole ollut Suomessa kunnolla menestyviä kantoja. Tilanne on kuitenkin korjaantumassa, sillä 
Mustilan Arboretumissa 60-70 vuotta kasvanut, maailmanlaajuisestikin poikkeuksellisen kestävä japaninmagnolia on saatu MTT Laukaassa mikrolisäämällä kaupalliseen taimituotantoon. Mustilan japaninmagnoliakanta on saanut lajikenimen Vanha Rouva.

Japaninmagnolia on vaativa kasvi. Pienenä taimena se on syytä suojata talvisin pakkaspeitteellä, kunnes se on vähintään $2 \mathrm{~m}$ korkea. Elimäen kirkonkylään istutettu mikrolisätty Mustilan japaninmagnolian taimi alkoi kukkia noin 10-vuotiaana ja 20-vuotiaana se on 6-7 m korkea. Kasvupaikaksi on syytä valita aurinkoinen, mutta pohjoistuulilta suojainen paikka. Erikoiskasvina tämä puu on erinomainen julkisten istutusten ja yksityispihojen helmi. Japaninmagnolia Vanha Rouva soveltuisi käytettäväksi myös jalostusohjelman kantaemona.

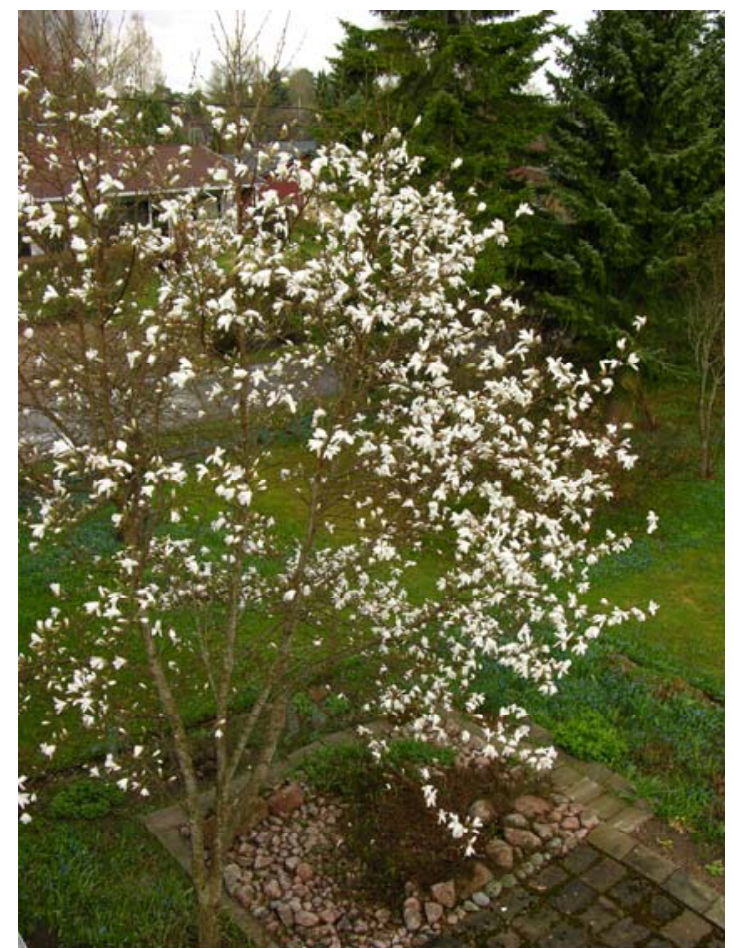

Kuva 3. Japaninmagnolia (Magnolia kobus). Vanha Rouva on 20 vuotiaana yli 6 m korkea, runsaasti kukkiva puu. Marjatta Uosukainen

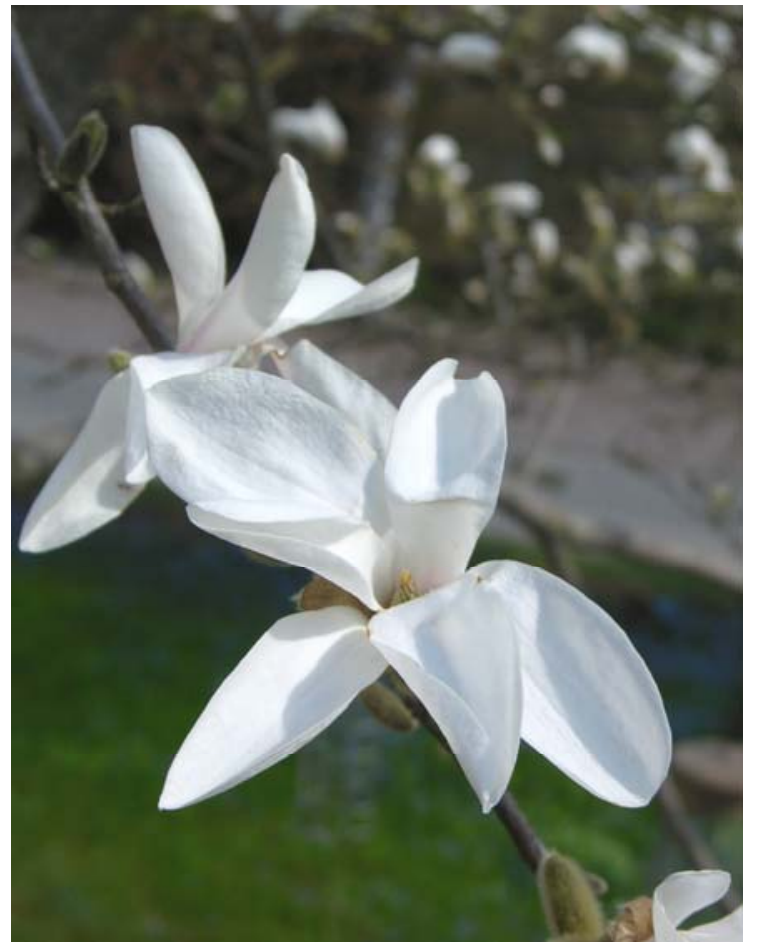

Kuva 4. Japaninmagnolian kukat ovat valkoisen ja hyvin suuret. Kukinta ajoittuu toukokuun alkuun, ennen lehtien puhkeamista. Marjatta Uosukainen

\section{Kääpiömanteli}

Ruusukasveihin (Rosaceae) kuuluvat mantelit ovat Suomessa harvinaisia, mutta punakukkainen kääpiömanteli (Prunus tenella Batsch) on omajuurisena osoittautunut kestäväksi Keski-Suomessakin. Pensas kukkii aikaisin keväällä runsain vaaleanpunaisin kukin juuri ennen lehtien puhkeamista. Esko Puupponen totesi vuonna 1971 kääpiömantelista: "Ihastuttava pikkupensas, jonka kauneutta kehuessa loppuvat superlatiivit" (Alanko \& Lagerström 2009). Siro, kasvupaikkavaatimuksiltaan vaatimaton pensas on vain runsaan metrin korkuinen. MTT:n Pälkäneen tutkimusaseman puistoistutuksista pelastettiin kääpiömantelikanta, joka on kestävä, mutta sen mikrolisäys on osoittautunut ongelmalliseksi versojen heikon juurtumisen vuoksi. Kanta on kuitenkin valittu geenivarasäilytettäväksi kasviksi erinomaisen talvenkestävyytensä vuoksi (Uosukainen 2006b). Lajike on osoittautunut MTT:n Laukaan toimipaikan kenttäistutuksissa täysin talvenkestäväksi. Kääpiömanteli on luonnonvarainen KeskiEuroopasta Etelä-Siperiaan (Hämet-Ahti ym. 1992).

\section{Keltakotakuusama}

Kotakuusamat (Weigela) kuuluvat kotakuusamakasveihin (Diervillaceae). Ne ovat Keski-Euroopassa hyvin suosittuja koristepensaita. Kaikki lajit ovat kotoisin Itä-Aasiasta Mantšuriasta, Japanista, Venäjän kaukoidästä ja Koreasta (Hämet-Ahti ym. 1992). Suomessa lajeja kasvatetaan hyvin vähän, sillä niillä on talvenaran kasvin maine. Keltakotakuusama (Weigela middendorfiana (Trautv. \& C.A.Meyer) K.Koch) on meillä kestävin laji, joka menestyy jopa Oulun korkeudella asti. Vanhemmiten pensaasta tulee hyvin tuuhea ja peittävä muodoltaan pyöreähkö pensas. Kukat ovat kellomaiset, kellanvalkeat ja niissä on teriön nielussa kellanruskeat laikut. Kukinta-aika on keväällä toukoheinäkuussa ja usein vielä loppukesällä ilmestyy myöhäiskukinta (Alanko \& Lagerström 2009). Suo- 
messa on viljelyssä lajike 'Jouni', joka on Amurin siemenkeruuretkellä vuonna 1976 kerätystä siemenaineistosta valittu kanta. Keltakotakuusama lähtee keväällä varhain kasvuun, mikäli se istutetaan aurinkoiselle ja lämpimälle paikalle ja saa keväthallavaurioita. Rakennusten pohjoisseinustoilla, missä lumi ja routa viipyvät keväällä kauimmin, kasvi ei altistu keväthalloille. Keltakotakuusama on helppo lisätä sekä mikrolisäyksellä että pistokkaista (Uosukainen 2006d). Laji ansaitsisi yleistyä puutarhoissa. Kestävyytensä vuoksi se olisi myös oivallinen kasvinjalostusohjelman kantalaji. Kasvurytmiltään mantereisen keltakotakuusaman ja merelliseen ilmastoon sopeutuneiden tarhakotakuusamien risteytyksistä syntyisi suurella todennäköisyydellä Suomen ilmastoon hyvin sopeutuva lajikkeisto.

\section{Suomalaiset puulajien erikoismuodot}

Vaikka luonnonvaraisten puuvartisten kasvien valikoimamme on melko suppea, Suomen metsissä tavataan erikoisia kotimaisten puulajien muotoja (Hämet-Ahti ym. 1992). Tunnetuimpia näistä ovat kuusen erikoismuodot, kuten surukuuset (kuva 5.), kultakuuset (kuva 6.), käärmekuuset, erilaiset tiheäkasvuiset kääpiökuuset sekä punalehtinen koivu että koivujen ja leppien liuskalehtiset muodot ja pihlajan riippuvaoksaiset ja pilarimalliset muodot. Osa harvinaisista muunnoksista on perinnöllisiä, kuten kultakuuset ja liuskalehtiset koivut. Metsäntutkimuslaitos (Metla) on rekisteröinyt kaikkiaan 1300 kotimaisten puulajien geneettisesti poikkeavaa yksilöä eri puolilta Suomea (Oskarsson \& Nikkanen 2001).

Erikoismuodot ovat poikkeavia myös kasvuvoimakkuudeltaan, eivät täten ole metsätalouden kannalta kiinnostavia, mutta soveltuvat hyvin koristearvonsa vuoksi viherrakentamiseen. Erikoismuotojen käyttöä rajoittaa niiden lisättävyys. Etenkin havupuiden lisäys on osoittautunut ongelmalliseksi. Vaikka muunnokset olisivat perinnöllisiä, niiden esiintymistiheys siemenjälkeläistössä saattaa olla alhainen. Siksi erikoismuodot on yleensä lisättävä kasvullisesti varttamalla, pistokkaista tai solukkolisäyksellä. Lisäysongelmiin haetaan ratkaisuja tutkimuksen keinoin, sillä kestävien kotimaisten kantojen käyttö olisi toivottavaa. Talviasuisessa puutarhassa havukasvit tuovat väriä ja luovat lämpimän tunteen. Kestävien havukasvien tarve korostuu mitä pohjoisemmas Suomessa siirrytään. (Oskarsson \& Nikkanen 2001). Taimimyymälöissä myynnissä olevat havukasvit ovat tällä hetkellä meillä tuontitavaraa ja niiden menestyminen on varsin vaihtelevaa ja niitä voidaan käyttää vain eteläisessä Suomessa.

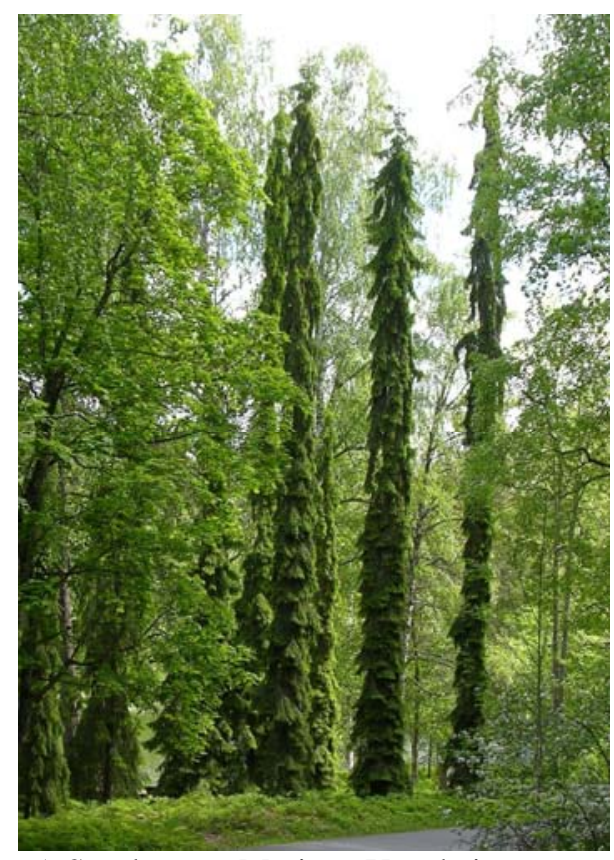

Kuva 5. Surukuuset. Marjatta Uosukainen

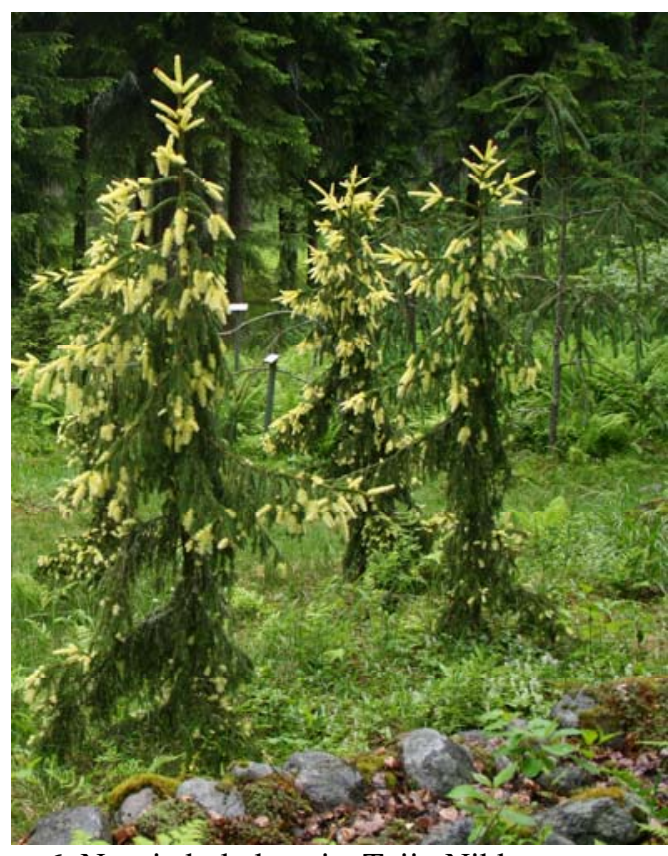

Kuva 6. Nuoria kultakuusia. Teijo Nikkanen

\section{Mikä merkitys on harvinaisuuksilla?}

Suomessa viimeisten 400-vuoden aikana kokeilluista tuhansista kasvilajeista, -lajikkeista ja -kannoista ankaran luonnonvalinnan seurauksena on heikoin aineisto karsiutunut pois (Väre ym. 2008). Maassamme vuosikymmeniä menestyneitä kasvikantoja alettiin määrätietoisesti kartoittaa SITRAn rahoittamassa KESKAS-tutkimuksessa 1980-luvun puolivälissä. Kartoituksen tuloksena kirjattiin yli 700 viherrakentamiselle arvokasta kasvikantaa (Alanko \& Tegel 1989). KESKAS-tutkimusta ovat seuran- 
neet aineistolla tehdyt kantavertailututkimukset, joiden pohjalta on valittu kasvikannat, joille on myönnetty FinE ${ }^{\circledR}$-laatumerkki (Juhanoja ym. 2001, Juhanoja 2003).

Suomessa menestyvän kasvin tulee olla sopeutunut kasvurytmiimme. Menestyvällä kasvilla tulee olla hyvä talviaikainen kylmänkestävyys ja kyky säilyttää lepotila myös kevättalven lämpiminä jaksoina. Kasvien keväisen kasvuunlähdön ja syystuleentumisen ajoituksen tulee olla sellainen, että kasvi ei ole hallanarka. Täten kasvien tulee olla sopeutuneita lyhyeen kasvukauteen. Kasvien tulee myös sietää sekä kasvukauden aikaista kuivuutta että talvella pakkaskuivumista. Ennen kaikkea, kasveilta edellytetään laajaa sopeutumiskyky vaihteleviin kasvuolosuhteisiin. Mikäli edellä esitetyt ominaisuudet yhdistyvät koristeelliseen kasvutapaan, runsaaseen kukintaan ja marjontaan, kyseessä ovatkin jo lajinsa superyksilöt. Ilmastolliselta sopeutumiskyvyltään erinomaisten kasvien laatuominaisuuksia, kuten koristearvoa voidaan parantaa risteyttämällä ne arempien, mutta esimerkiksi koristearvoltaan toivottujen lajien kanssa.

Ilmaston lämpeneminen on kiihdyttänyt tarvetta uusien puuvartisten kasvien jalostukseen myös viherrakentamisen tarpeisiin, sillä kylmässä ilmanalassa viherrakentamiseen soveltuvien puuvartisten kasvien valikoima on rajoittunut (Hämet-Ahti 2008) ja ilmastonmuutos supistaa valikoimaa entisestään. Nurinkurista on, että ilmaston lämpeneminen merkinnee lisääntynyttä pakkasvaurioiden riskiä monille puuvartisille kasveille, joita pitkittynyt lämmin syksy ja aikainen kevät altistavat sekä talvivaurioille että keväthallavaurioille.

Suomesta löydettyjä aineistoja tulee hyödyntää nykyistä laajemmin ja monipuolisemmin. Meillä kestäviksi osoittautuneet kasvit luovat perustan suomalaiselle taimituotannolle ja viherrakentamiselle ja olisivat erinomainen pohja kasvinjalostukselle. Suomalaiset taimistot ovat esimerkillisesti luottaneet tuotannossaan kotimaisiin lisäysaineistoihin, sillä taimistojen myynnistä $79 \%$ on omaa tuotantoa (Uimonen 2009). Kehitysmaissa suurin huoli on elintarviketuotannon riittävyys, mutta teollisuusmaissa on todettu, että ihminen ei elä pelkästä leivästä. Sivistysvaltion mittana voidaan käyttää elinympäristön viihtyisyyttä, jonka näkyvä ilmenemismuoto on tapa miten puutarhakulttuuria arvostetaan valtakunnassa. Tutkimuksella on tärkeä tehtävä viedä alan kehitystä eteenpäin ja ilmastonmuutoksen uhkan tuoma muutospaine vaatii panostusta edelleen.

\section{Kirjallisuus:}

Alanko, P. \& Tegel, S. 1989. KESKAS-tutkimus. Kestäviä Koristekasveja viherrakentamisen tarpeisiin. SITRA Sarja B nro 98: 111 s. Helsinki. ISBN 951-563-219-6.

Alanko, P. \& Lagerström, M. 2009. Puutarhan koristepensaat. Kustannusosakeyhtiö Tammi. Kariston Kirjapaino Oy, Hämeenlinna. p. 288. ISBN 978-951-31-4797-6

Cox, P.A., 1979. The larger species of Rhododendron. B.T. Batsford Ltd. Lontoo. 352 s. ISBN 0-7134-1747-1.

Hagman, M. \& Autio, A. 1999. Mustilanalppiruusun tarina (The story of the Tigerstedtii rhododendron). Sorbifolia 30: 25-30.

Hauta-aho, 2006. Pihasyreenilajikkeita Helsingin kaupungin viheralueilla. Helsingin kaupungin rakennusviraston julkaisuja 2006:1. $36 \mathrm{~s}$.

Hämet-Ahti, L. 1970. Bioklimaattisesti Suomea vastaavista alueista. Dendrologian Seuran Tiedotuksia. 1970: 211.

Hämet-Ahti, L. , Palmèn, A., Alanko, P. \&Tigerstedt, P.M.A. 1992. Suomen puu- ja pensaskasvio. Dendrologian Seura - Dendrologiska Sällskapet ry. Yliopistokirjapaino, Helsinki. 373 s. ISBN951-96557-0-0.

Hämet-Ahti, L. 2008. Suomen alkuperäinen puuvartislajisto on niukka. Teoksessa: Henry Väre, Aune Koponen, Leena Hämet-Ahti, Max. Hagman \& Juha Raisio (toim.) 2008. Puiden jäljillä. 400 vuotta dendrologian historiaa.Publications of the Finnish Dendrological Society 9: 3-6. ISBN 978-951-96557-3-4. Kirjapaino Yliopistopaino, Helsinki.

Häyrynen, M. 2008. Kartanoiden ja pappiloiden puutarhat. Teoksessa: Henry Väre, Aune Koponen, Leena Hämet-Ahti, Max. Hagman \& Juha Raisio (toim.) 2008. Puiden jäljillä. 400 vuotta dendrologian historiaa.Publications of the Finnish Dendrological Society 9: 53-69. ISBN 978-951-96557-3-4. Kirjapaino Yliopistopaino, Helsinki.

Juhanoja, S. 2003. FinE ${ }^{\circledR}$-kasvivalikoima laajenee. MTT:n selvityksiä (2003):42, s. 53-54 http://www.mtt.fi/mtts/pdf/mtts42.pdf, verkkojulkaisu päivitetty 1.8.2003.

Juhanoja, S., Aaltonen, M., Aflatuni, A., Heinonen, A., Kemppainen, R., Paasikivi, P., Sorvari, K., Vehkalahti, M. \& Virtanen, A. 2001. Tutkittuja kasveja viherrakentamisen tarpeisiin. KESKAS-valintakokeet MTT:ssä vuosina 1988-2000. MTT:n julkaisuja. Sarja A (2001):98, 60 s. + 11 liitettä. http://www.mtt.fi/asarja/pdf/asarja98.pdf. 
Jäppinen, J.1996. Luonto asemakaavassa. Teoksessa: Jussi Jäppinen (toim.) 1996. Pikkukaupungin pihoja ja puistoja. Kaupunkivihreän kehitysvaiheita Jyväskylässä. Jyväskylän Puutarhaseura ry, ja Jyväskylä Seura ry. Gummerus Kirjapaino Oy, Jyväskylä. ISBN 952-90-7860-9. s. 14-15.

Koponen, A. 2008. Arboretum Mustila. Teoksessa: Henry Väre, Aune Koponen, Leena Hämet-Ahti, Max. Hagman \& Juha Raisio (toim.) 2008. Puiden jäljillä. 400 vuotta dendrologian historiaa.Publications of the Finnish Dendrological Society 9:122-124. ISBN 978-951-96557-3-4. Kirjapaino Yliopistopaino, Helsinki. 328 s.

Mustiala, V. 2005. Helsingin lehtipuut. Pohjoiset taajamapuut-tutkimuksen osaraportti. Helsingin rakennusviraston julkaisut 2005:06. Helsingin kaupungin rakennusvirasto. Dark Oy. 88 s. ISBN 952-473-568-7.

Nitzelius, T.G. 1970. Rhododendron brachycarpum D.Don ex Don ssp. tigerstedtii eine neue Unterart. Vorläufige Mitteilung. Deitsche Baumschule 22(7): 207-212.

Nummi, A. 2008. Puita ja istutuksia autonomian ajalla. Teoksessa: Henry Väre, Aune Koponen, Leena HämetAhti, Max. Hagman \& Juha Raisio (toim.) 2008. Puiden jäljillä. 400 vuotta dendrologian historiaa.Publications of the Finnish Dendrological Society 9: 71-110. ISBN 978-951-96557-3-4. Kirjapaino Yliopistopaino, Helsinki. $328 \mathrm{~s}$.

Oskarsson, O. \& Nikkanen, T. 2001. Metsäpuiden erikoismuotoja kultakuusesta luutakoivuun. Metsäntutkimuslaitoksen tiedonantoja 670: 1-54.

Räty, E. 2009. Viheralueiden puut \& pensaat. Puutarhaliiton julkaisuja nro 353.Viides köynnöksillä laajennettu painos. 224 s. Helsinki. ISBN 978-951-8942-82-8.

Räty, E. \& Alanko, P. (toim.) 2004. Viljelykasvien nimistö. Puutarhaliiton julkaisuja nro 328.199 s. Helsinki. ISBN 951-8942-57-9.

Temmes, O. 2007. Koristeomenapuulajikkeita Helsingin kaupungin viheralueilla. Helsingin kaupungin rakennusviraston julkaisuja 2007:16/Katu- ja puisto-osasto, $42 \mathrm{~s}$.

Uimonen, J. 2009. Taimitarhatuotannon tutnnuslukuja seurataan. Puutarha \& Kauppa 2009, 25-26:73.

Uosukainen, M. 1992. Rhododendron brachycarpum ssp. tigerstedtii Nitz. - A transmitter of extreme frosthardiness. Selection and breeding woody ornamentals. Acta Horticulturae 320: 77-83.

Uosukainen, M. 1993. Arboretum Mustila - a gene bank for Rhododendron breeding. Teoksessa: Mustila Arboretum as a centre for introducing and breeding shrubs and trees. Proceedings of the $90^{\text {th }}$ Anniversary Jubilee Symposium of Mustila Arboretum, Moisio Manor, 19-21 August 1992. Yliopistopaino. Helsinki. s. 70-80. ISBN 952-90-5015-1.

Uosukainen, M. 2006a. Alppiruusulajikkeet ja niiden jalostus. Maataloustieteen Päivät 2004. www.agronet.fi/maataloustieteellinenseura. $4 \mathrm{~s}$.

Uosukainen, M. 2006b. Erikoiskasviryhmän säilytysohjeet. Teoksessa: Marja Aaltonen, Kristiina Antonius, Sirkka Juhanoja, Vesa Järvelin, Jaana Laamanen, Anna Nukari, Riitta Peräinen, Mia Sahramaa, Marjatta Uosukainen ja Marja Uusitalo 2006. Suomen kansallisten kasvigeenivarojen pitkäaikaissäilytysohjeet. Viherrakentamisen kasvit. Maa- ja elintarviketalous 91: 43-58. ISBN-10 952-487-077-0. MTT. Jokioinen. 253 s.

Uosukainen, M. 2006c. Hydrangea-ryhmän säilytysohjeet. Teoksessa: Marja Aaltonen, Kristiina Antonius, Sirkka Juhanoja, Vesa Järvelin, Jaana Laamanen, Anna Nukari, Riitta Peräinen, Mia Sahramaa, Marjatta Uosukainen ja Marja Uusitalo 2006. Suomen kansallisten kasvigeenivarojen pitkäaikaissäilytysohjeet. Viherrakentamisen kasvit. Maa- ja elintarviketalous 91: 65-70. ISBN-10 952-487-077-0. MTT. Jokioinen. 253 s.

Uosukainen, M. 2006d. Weigela-ryhmän säilytysohjeet. Teoksessa: Marja Aaltonen, Kristiina Antonius, Sirkka Juhanoja, Vesa Järvelin, Jaana Laamanen, Anna Nukari, Riitta Peräinen, Mia Sahramaa, Marjatta Uosukainen ja Marja Uusitalo 2006. Suomen kansallisten kasvigeenivarojen pitkäaikaissäilytysohjeet. Viherrakentamisen kasvit. Maa- ja elintarviketalous 91: 190-195. ISBN-10 952-487-077-0. MTT. Jokioinen. $253 \mathrm{~s}$.

Uosukainen, M. 2008. Alppiruusut, atsaleat ja ruusut - kestävien koristepensaiden jalostusta. Teoksessa: Henry Väre, Aune Koponen, Leena Hämet-Ahti, Max. Hagman \& Juha Raisio (toim.) 2008. Puiden jäljillä. 400 vuotta dendrologian historiaa. Publications of the Finnish Dendrological Society 9: 231-238. ISBN 978-951-96557-34. Kirjapaino Yliopistopaino, Helsinki. $328 \mathrm{s.}$

Uosukainen, M. \& Tigerstedt, P.M.A. 1988. Breeding of frosthardy rhododendrons. Journal of Agricultural Science in Finland 60: 235-254.

Väre, H., Koponen, A., Hämet-Ahti, L., Hagman, M. \& Raisio, J. (toim.) 2008. Puiden jäljillä. 400 vuotta dendrologian historiaa.Publications of the Finnish Dendrological Society 9: $328 \mathrm{s.}$ 